\title{
Monitoring Technique For Heavy Metal Assessment In Different Locations of Punjab Using Feathers of Feral Pigeons (Columbia Livia)
}

Simranjit Kaur

Punjab Agricultural University

Prerna Sood ( $\nabla$ vohra.prema123@gmail.com)

Punjab Agricultural University

\section{Research Article}

Keywords: Feral Pigeon, Feathers, Heavy Metals, Pollution, Punjab

Posted Date: June 10th, 2021

DOI: https://doi.org/10.21203/rs.3.rs-582847/v1

License: () (7) This work is licensed under a Creative Commons Attribution 4.0 International License. Read Full License 


\section{Abstract}

Heavy metals are one of the major environmental issues due to their large number of sources and their diligence. The amount of heavy metals in washed and unwashed feral pigeon feathers were investigated in this paper. The feathers were collected from five distant locations: Agronomy Farm Punjab Agricultural University, Ludhiana, Cold Storage Jalandhar Bypass, Cold Storage Mullanpur, Jalandhar FCl and Hoshiarpur FCl. Inductively coupled plasma optical emission spectrometry was used to analyse the concentration of heavy metals (Arsenic, Chromium, Cadmium and Lead). The high metal concentration in two areas (Hoshiarpur FCl and Jalandhar Bypass) as compare to other three areas is due to much more industries and anthropogenic activities. Mean values of As, Cd, $\mathrm{Pb}$, and $\mathrm{Cr}$ were statistically significant different in the five collection sites. Metal concentrations are related to contact time or external exposure, as shown by significant differences in $\mathrm{Cd}, \mathrm{Pb}$, and $\mathrm{Cr}$ concentrations in washed and unwashed feathers. According to our analysis, bird's feather can be used to quantify the environmental heavy metals. It can also be recommended that unwashed feathers were proficient to explore exogenous and endogenous absorption of the heavy metals.

\section{Introduction}

Birds occupy almost every habitat on earth, are present in large numbers and in different variety and forms. In India, Agriculture sector experience the indiscriminate use of pesticides which leads to mortality of many birds (Dhindsa et a/ 1994). As a result of urbanisation and industrialization, a significant number of contaminants have entered the atmosphere. Heavy metals are the pollutants that enter the food chain through manmade as well as natural sources, becoming very harmful to humans and animals (Swaileh and Sansur 2006). Metals enter the body through food and can be eliminated or accumulated. Metal elimination in birds occurs in feathers (Braune et al. 2002; Lewis and Furness 1991; Braune 1987). These pollutants include the pesticides and trace metals. Heavy metals are those elements that occur in small concentrations in the environment that is $5 \mathrm{~g} / \mathrm{cm}^{3}$ (Adriano 1986). Metals (Fe, Cu, Zn and $\mathrm{Mn}$ ) are considered to be essential micronutrients for human survival. The main sources of metals in the atmosphere are pesticides, fertilizers, oil combustion, emissions from the vehicles, and burning of industrial residues (Tavares and Carvalho 1992; Egreja Filho 1993).

Bioindicators for environmental contamination include fish, amphibians, terrestrial avians and beast (Fisk et al. 2005). Birds are useful bioindicators as they get exposure from a range of chemicals. Feathers can uptake metals by three ways; by having direct contact with air, water and soil, through food and by preening process (Bianchi 2008). Feathers are used for metal contamination because they can be easily collectable without harming the bird (Goede and de Bruin 1986; Burger 1993). Metals may be processed, collected or even excreted until they've been absorbed into the body (Dauwe et al. 2000). Heavy metal levels estimated from bird's feathers is the total of endogenous and exogenous fractions. Exogenous exposure is during preening and direct exposure to air, water and soil. Endogenous exposure is due to ingestion of heavy metals with food then absorbed into the blood from the intestine and accumulates in the liver and kidney (Wayers 2002)

Pigeons are the birds that reside in urban areas, villages and other sites where there is plenty of food. Due to their higher respiratory rate, metabolic rate, reduced mobility, and feeding habit, pigeons are very attractive bioindicators (Nam and Lee 2006). Since, 1960s fringes have been used for metal biomonitoring (Burger and Gochfeld 1993), because this method is effective for metal quantification and collection of feathers does not harm the birds. A number of studies have been reported by using unwashed (Nam et al. 2004) and washed feathers (Almansour 2004; Dauwe et al. 2000; Swaileh and Sansur 2006). The use of washed feathers in research allows for the study of metal concentrations deposited in the atmosphere and those absorbed by tissues.

Metals in bird feathers come from both endogenous and exogenous sources. Exogenous pollution occurs when feathers come into direct contact with the environment and endogenous contamination takes place by ingestion of heavy metals with food and get deposited in the feathers during their formation (Brait et al. 2010). In India heavy metal contamination studies on birds are limited. In this paper we quantify heavy metals in the washed and unwashed feathers of pigeon ( $C$. livia) to determine the differences between the levels of metals in feathers.

\section{Material And Method}

Study area PUNJAB: Punjab state is located in North West India alongside of Pakistan from $29^{\circ} 32^{\prime}$ North and $73^{\circ} 55^{\prime}$ east. In the North it is surrounded by $\mathrm{J} \&$ $\mathrm{K}$, in the east by Himachal Pradesh and in the South by Haryana and Rajasthan. It is one of the smallest states of India with geographical area of 50,362 square kilometres. Pigeon feather samples were obtained from five sites: Agronomy farm PAU, Jalandhar bypass Ludhiana, Mullanpur, Jalandhar FCl and Hoshiarpur FCl. The areas were selected because they were near to G.T. Road which accounts for traffic density and also due to industrial activities.

Pigeon feathers collection: Feather samples of Columba livia were collected from the nesting sites from above mentioned sites. Randomly twenty feather samples were collected without harming the birds and preserved them in zip lock bags by mentioning date and site of collection. They were placed in freezer till further analysis.

Sample preparation: After that, the samples were taken out of the freezer and put on a filter paper sheet to be condition. They were air dried in an oven for 24 hours at 60 degrees Celsius. Feathers were washed with distilled water followed by A.P acetone twice and samples were split into two groups: (1) washed feathers (2) unwashed feathers. After washing, samples were air dried at $60^{\circ} \mathrm{C}$ in oven for 24 hours.

Analytical proceedings: $1 \mathrm{gram}$ of samples were weighed and put in digestion flask and to it 10ml of Diacid (Perchloric acid: Nitric acid in the ration of 3:1) was added. The flasks were then placed in oven with two blanks. In a 52 minute time, the temperature of the oven was steadily increased from room temperature to $121^{\circ} \mathrm{C}$. After the digestion the extracts were transferred to a flask and its final volume was made upto $50 \mathrm{ml}$. Then, the analysis was done using Inductively Coupled Plasma Atomic Emission Spectrometer (ICAP-AES) at The Department of Soils, PAU, Ludhiana. The standard conditions were maintained for the heavy metal estimation. The glassware was disinfected one night before with $5 \%$ nitric acid solution. 
Statistical analysis: CPCS1 statistical software was used for statistical analysis and the differences were considered significant at P $\leq 0.05$ probability.

\section{Results And Discussion}

Table 1, Table 2 and Table 3 display the results of metal analysis in both types of feathers under study and then mean metal concentrations were compared (Table 4).

\section{Lead}

Lead $(\mathrm{Pb})$ is the ubiquitous toxic metal present in low concentrations in the environments. Lead can originate from natural sources such as volcanos, erosion, disasters, ceramic industries and food industries.

In Figure 2 highest and lowest concentrations of lead were found at Jalandhar Bypass, Ludhiana. This is due to the air pollutants coming from vehicles emission and from the burning of fossil fuels. In washed feathers, collected at Jalandhar bypass, Agronomy farm PAU Ludhiana, Mullanpur, Jalandhar FCl, Hoshiarpur $\mathrm{FCl}$ has average contents of lead as $0.730,0.104,0.135,0.121$ and 0.394 , respectively (Table 2). Mean lead concentration at Jalandhar bypass, Ludhiana $(0.730 \mathrm{ppm})$ was significantly higher compared to rest of the locations and lowest was recorded at Agronomy farm, PAU (0.104 ppm).

Similalry, in unwashed samples of Jalandhar bypass, Ludhiana showed higher concentrations of lead with an average content of 1.2 ppm and lowest was recorded at Agronomy farm, PAU (0.200 ppm) and Jalandhar $\mathrm{FCl}(0.200 \mathrm{ppm})$ (Table 3). No significant difference in average lead concentrations was found at the Agronomy farm, Ludhiana and in Jalandhar $\mathrm{FCl}$, which is due to less concentration of this metal in both the locations.

Tsuji et al. (2002) determined lead concentrations for several bird species in a heavily hunted region of Canada reported a range of lead concentrations more than $20 \mathrm{ug} / \mathrm{g}$ which indicates toxicity of lead in wild mallard ducks.

A study conducted by Kim et al. (2007) on two species of heron to study the metal concentration in feathers reported that lead concentration were different in two heron species. While studying the feathers of small birds in Punjab, India, Bianchi et al (2008) discovered that lead concentrations are directly linked to feather exposure time. As a result, unwashed feathers are the most reliable indicator of lead levels in the water and soil.

Sani et al (2019) conducted a study for the assessment of heavy metals in feather of birds reported highest concentration of lead followed by cadmium, chromium and manganese. So higher concentration of lead in unwashed feathers in Jalandhar bypass not only show the pattern of lead deposition but a way to monitor lead levels in the environment through feathers.

\section{Cadmium}

Cadmium (Cd) is contained in the atmosphere in very low concentrations. In washed feathers (Table 2), the concentrations were $0.005,0.018,0.0055,0.025$ and $0.017 \mathrm{ppm}$, respectively at Agronomy farm Ludhiana, Jalandhar bypass, Mullanpur, Jalandhar FCl and Hoshiarpur FCl. The highest cadmium concentration was recorded at Jalandhar bypass $(0.18 \mathrm{ppm})$ and Hoshiarpur $\mathrm{FCl}(0.17 \mathrm{ppm})$ which were also statistical at par with each other.

Similalry, at Agronomy farm PAU, Jalandhar bypass Ludhiana, Mullanpur, Jalandhar FCl and Hoshiarpur FCl, the average levels of Cd were 0.01 , $0.3,0.01$, 0.004 and $0.2 \mathrm{ppm}$ in unwashed feathers. The highest concentration of cadmium in unwashed feathers was found at Jalandhar bypass (0.300 ppm) and Hoshiarpur $\mathrm{FCl}(0.200$ ppm) (Table 3; Fig. 2), which is due to vehicular pollution and a number of factories in the region, resulting in higher levels of cadmium in the atmosphere. So, pigeons in urbanized areas are more contaminated as compared to rural ones (Nam and Lee 2006).

Jayakumar et al (2011) demonstrated metal pollution in six bird's species, reported that level of cadmium was less than $1 \mathrm{ug} / \mathrm{g}$ in four species with significant variation ( $p$ greater than 0.05) with exception in Jungle Babbler and Common Myna.

\section{Chromium}

Chromium ( $\mathrm{Cr}$ ) is a vital element that can be present in trace amounts in the world. High chromium concentrations in animal tissue are due to agricultural activities, anthropic activities such as the production of bricks and emissions from vehicles (Movalli 2000). Our study showed low chromium levels in the washed feathers compared to unwashed feathers, with higher chromium levels at Hoshiarpur $\mathrm{FCl}$ ( $\mathrm{Tables} 2$ and 3 ). Figure 2 shows the order of mean concentartions respectively Hoshiarpur FCl> Jalandhar bypass > Mullanpur> Jalandhar FCl> Agronomy farm, which can be explained by TPS accumulation in urbanised bird feathers. This demonstrates that chromium exposure in covered or less urbanised areas comes from the animals' diet.

Muralidharan (2018) reported higher level of chromium, magnesium and iron in the feathers of young house sparrow residing in Mumbai city, India.

Sahu et al (2019) revealed high chromium concentration that is $1.819 \mathrm{ppm}$ in the feathers of pigeons (C. livia) at one site as compared to other selected sites at Ajmer city, Rajasthan.

\section{Arsenic}

Arsenic is a trace element found in the environment and in the living beings. It is released into environment through agricultural practices including the application of fertilizers and pesticides. The mean concentration of As at Hoshiarpur, Jalandhar FCl, Agronomy farm, cold storage Jalandhar bypass, cold storage Mullanpur, Ludhiana was 0.014 ppm, 0.004ppm, 0.008 ppm, 0.033, 0.01 ppm in washed feathers and was $0.02,0.005,0.009,0.05$ and 0.03 ppm in unwashed feathers, respectively. 
Wiemeyer et al. (1980) studied about the concentration in the four species of owls and the highest concentration found among them was $0.40 \pm 0.30 \mathrm{mg} / \mathrm{kg}$, that is lower than the concentration of $5 \mathrm{mg} / \mathrm{kg}$ found in the USA in an area of possible As pollution. Very limited studies were there to use the feathers for quantification of arsenic, which makes it difficult to determine whether the amount of As recorded is significant or not (Burger et al. 2015).

\section{Conclusion}

The birds' feathers contained different levels of heavy metals which significantly reveal the nature of the sites (Sani et al. 2019). Heavy metals do not undergo biodegradation in the environment instead these undergo biomagnification in the exposed organisms (Pandiyan et al. 2020). Bird feathers can be used for monitoring environmental pollution because it does not require sacrificing of birds and feathers have good correlation with concentrations of metals in the atmosphere (Swaileh and Sansur 2006; Nam et al. 2004; Almansour 2004; Dauwe et al. 2002, 2003).

The heavy metals under study viz. Lead, chromium, and cadmium, are present in the atmosphere and are deposited in feathers of birds or reach the tissues through diet, according to our findings. Finally, the study of pigeon feathers can be used to measure and track metal concentrations in the environment $(C$. livia). Unwashed feathers are preferable for identifying metals ingested through the diet as well as those absorbed through the atmosphere, while the other type of feathers are effective for quantification metal pollution which originate from food and atmosphere.

\section{References}

1. Adriano DC (1986) Trace elements in the terrestrial environment. Springer, New York

2. Almansour MI (2004) Using feathers as a biological indicator of lead environmental pollution. Pak J Biol Sci 7(11):1884-1887

3. Bianchi N, Ancora S, Di Fazio N, Leonzio C (2008) Cadmium, lead, and mercury levels in feathers of small passerine birds: Noninvasive sampling strategy. Environ Toxicol Chem 27(10):2064-2070

4. Brait $\mathrm{CHH}$, Antoniosi FNR (2010) Development and application of passive sampling of air pollutants for $\mathrm{Cd}, \mathrm{Cr}, \mathrm{Pb}, \mathrm{Cu}, \mathrm{Fe}, \mathrm{Mn}, \mathrm{Zn}$ and total particles monitoring. Química Nova 33(1):7-13

5. Braune BW (1987) Comparison of total mercury levels in relation to diet and molt for nine species of marine birds. Arch Environ Contam Toxicol 16:217224

6. Braune BW, Gaskin DE (1987) Mercury levels in Bonaparte's gull (Larus philadelphia) during autumn molt in the Quoddy region, New Brunswick, Canada. Arch Environ Contam Toxicol 16:539-549

7. Braune BW, Donaldsong M, Hobson KA (2002) Contaminant residues in seabird eggs from the Canadian Arctic. II. Spatial trends and evidence from stable isotopes for intercolony differences. Environ Poll 117:133-145

8. Burger J, Tsipoura N, Niles LJ, Gochfeld M, Dey A, Mizrahi D (2015) Mercury, lead, cadmium, arsenic, chromium and selenium in feathers of shorebirds during migrating through Delaware Bay, New Jersey: comparing the 1990s and 2011/2012. Toxics 3:63-74

9. Burger J (1993) Metals in avian feathers: Bioindicators of environmental pollution. Rev Environ Toxicol 5:203-311

10. Burger J, Gochfeld M (1993) Lead and cadmium accumulation in eggs and fledgling seabirds in the New York bight. Environ Toxicol Chem 12:261-267

11. Dauwe T, Bervoets L, Blust R, Eens M (2002) Tissue levels of lead in experimentally exposed Zebra Finches (Taeniopygia guttata) with particular attention on the use of feathers as biomonitors. Arch Environ Contam Toxicol 42:88-92

12. Dauwe T, Bervoets L, Blust R, Pinxten R, Eens M (2000) Can excrement and feathers of nestling songbirds be used as biomonitors for heavy metal pollution? Arch Environ Contam Toxicol 39:541-546

13. Dauwe T, Bervoets L, Pinxten R, Blust R, Eens M (2003) Variation of heavy metals within and among feathers of birds of prey: Effects of molt and external contamination. Environ Pollut 124:429-436

14. Dhindsa MS, Saini HK (1994) Agricultural Ornithology; an Indian perspective. J Bio Sci 19:391-402

15. Egreja Filho FB (1993) Avaliação da ocorrência e distribuição dos metais pesados na compostagem de lixo domiciliar urbano. Dissertação, Universidade Federal de Viçosa

16. Fisk AT, Wit AA, Wayland M, Kuzyk ZZ, Burgess N, Letcher R (2005) An assessment of the toxicological significance of anthropogenic contaminants in Canadian arctic wildlife. Sci Total Environment 351-352:57-93

17. Goede AA, DeBruin M (1986) The use of feathers for indicating heavy metal pollution. Environ Monit Assess 7:249-256

18. Jayakumar R, Muralidharan S (2011) Metal Contamination in Select Species of Birds in Nilgiris District, Tamil Nadu. India Bull Environ Contam Toxicol 87:166-170

19. Kim J, Koo TH (2007) The Use of Feathers to Monitor Heavy Metal Contamination in Herons. Korea Arch Environ Contam Toxicol 53:435-441

20. Lewis SA, Furness RW (1991) Mercury accumulation and excretion by laboratory reared black-headed Gulls (Larus ridibundus) chicks. Arch Environ Contam Toxicol 21:316-320

21. Movalli PA (2000) Heavy metal and other residues in feathers of laggar falcon Falco biarmicus jugger from six districts of Pakistan. Environ Pollut 109:267-275

22. Muralidharan L (2018) A study on heavy metal accumulation in the feathers of young house sparrow passer domesticus residing in mumbai city, india. Res J Life Sci Bioinform Pharm Chem Sci 4(3):493

23. Nam DH, Lee DP (2006) Monitoring for Pb and Cd pollution using feral pigeons in rural, urban and industrial environments of Korea. Sci Total Environ 357:288-295 
24. Nam DH, Lee DP, Koo TH (2004) Factors causing variations of lead and cadmium accumulation of feral pigeons (Columba livia). Environ Monit Assess 95:13-22

25. Pandiyan J, Jagadheesan R, Karthikeyan G, Mahboob S, Ghanim K, Misned FL, Ahmed Z, Krishnappa K, Elumalai K, Govindarajan M (2020) Probing of heavy metals in the feathers of shorebirds of Central Asian Flyway wintering. grounds Scientific Reports 10:22118

26. Sahu H, Patan S, Sharma V, Mathu P (2019) Estimation of Heavy Metal Residues from the Feathers' of Blue Rock Pigeon (Columba livia) from Ajmer City. Rajasthan Res J Chem Environ Sci 7:8-14

27. Sani A, Lawal Abdullahi I, Salmanu T (2020) Assessment of heavy metals profile in feathers of birds from Kano metropolis, Nigeria, in 2019. Environ health eng Manag 7(4):257-262

28. Scheuhammer AM (1987) The chronic toxicity of aluminium, cadmium, mercury, and lead in birds: Review. Environ Pollut 46:263-295

29. Swaileh KM, Sansur R (2006) Monitoring urban heavy metal pollution using the house sparrow (Passer domesticus). J Environ Monitor 8:209-213

30. Tavares TM, Carvalho FM (1992) Assessment of human population exposure to heavy metals in the environment: Examples from Bahia. Brazil Química Nova 15(2):147-153

31. Tsuji LJS, Karagatzides JD, Younds J, Nieboer E (2002) Liver lead concentrations of several bird species from the western James bay region of Northern Ontario, Canada: do the data support the Canadian non-toxic legislation? Bull Environ Contam Toxicol 69:309-313

32. Weyers T, Bervoets L, Blust R, Eens M (2002) Tissue levels of lead in experimentally exposed zebra finches (Taeniopygia gut- tata) with particular attention on the use of feathers as biomonitors. Arch Environ Contam Toxicol 42:88-92

33. Wiemeyer S, Lamont T, Locke L (1980) Residues of environmental pollutants and necropsy data for eastern United States ospreys, 1964-1973. Estuaries 3:155-167

\section{Tables}

Table 1 Average concentration, sample standard deviation (SSD) in samples from different collection sites

Mean concentrations in (ppm) in washed feathers

\begin{tabular}{|c|c|c|c|c|c|c|}
\hline \multirow[b]{2}{*}{$\begin{array}{l}\text { Heavy } \\
\text { Metals } \\
\text { conc. } \\
\text { (ppm) }\end{array}$} & \multirow{2}{*}{$\mathbf{n}$} & \multicolumn{4}{|l|}{ LOCATIONS } & \multirow[b]{2}{*}{$\begin{array}{l}\mathrm{HOSHI} / \\
\mathrm{FCl}\end{array}$} \\
\hline & & $\begin{array}{l}\text { AGRONOMY } \\
\text { FARM }\end{array}$ & $\begin{array}{l}\text { JALANDHAR } \\
\text { BYPASS }\end{array}$ & MULLANPUR & JALANDHAR FCI & \\
\hline $\begin{array}{l}\text { Arsenic } \\
\text { (As) }\end{array}$ & 20 & $0.008 \pm 0.0004$ & $0.033 \pm 0.0016$ & $0.010 \pm 0.0005$ & $0.004 \pm 0.0002$ & $0.014 \pm 1$ \\
\hline $\begin{array}{l}\text { Cadmium } \\
\text { (Cd) }\end{array}$ & 20 & $0.005 \pm 0.0003$ & $0.018 \pm 0.0009$ & $0.006 \pm 0.0003$ & $0.003 \pm 0.0001$ & $0.017 \pm 1$ \\
\hline $\begin{array}{l}\text { Chromium } \\
\text { (Cr) }\end{array}$ & 20 & $0.078 \pm 0.0039$ & $0.213 \pm 0.0106$ & $0.072 \pm 0.0036$ & $0.045 \pm 0.0023$ & $0.296 \pm 1$ \\
\hline Lead $(\mathrm{Pb})$ & 20 & $0.104 \pm 0.0052$ & $0.730 \pm 0.0365$ & $0.135 \pm 0.0067$ & $0.121 \pm 0.0061$ & $0.394 \pm 1$ \\
\hline
\end{tabular}

Mean concentrations in (ppm) in unwashed feathers

\begin{tabular}{|c|c|c|c|c|c|c|}
\hline \multirow[b]{2}{*}{$\begin{array}{l}\text { Heavy } \\
\text { Metals }\end{array}$} & \multirow{2}{*}{$\mathbf{n}$} & \multicolumn{4}{|l|}{ LOCATIONS } & \multirow[b]{2}{*}{$\begin{array}{l}\mathrm{HC} \\
\mathrm{FC}\end{array}$} \\
\hline & & $\begin{array}{l}\text { AGRONOMY } \\
\text { FARM }\end{array}$ & $\begin{array}{l}\text { JALANDHAR } \\
\text { BYPASS }\end{array}$ & MULLANPUR & JALANDHAR FCI & \\
\hline $\begin{array}{l}\text { Arsenic } \\
\text { (As) }\end{array}$ & 20 & $0.0090 \pm 0.0005$ & $0.0500 \pm 0.0025$ & $0.0300 \pm 0.0015$ & $0.0050 \pm 0.0003$ & 0.1 \\
\hline $\begin{array}{l}\text { Cadmium } \\
\text { (Cd) }\end{array}$ & 20 & $0.0100 \pm 0.0050$ & $0.3000 \pm 0.0150$ & $0.0100 \pm 0.0005$ & $0.0040 \pm 0.0002$ & 0.2 \\
\hline $\begin{array}{l}\text { Chromium } \\
\text { (Cr) }\end{array}$ & 20 & $0.0800 \pm 0.0040$ & $0.4000 \pm 0.0200$ & $0.0900 \pm 0.0045$ & $0.0700 \pm 0.0035$ & 0.4 \\
\hline Lead (Pb) & 20 & $0.2000 \pm 0.0100$ & $1.2000 \pm 0.0600$ & $0.2500 \pm 0.0125$ & $0.2000 \pm 0.0100$ & $0 .:$ \\
\hline
\end{tabular}

Table 2: Mean heavy metals concentration in washed feathers from five collection sites 


\begin{tabular}{|lllll|}
\hline Location & As & $\mathrm{Cd}$ & $\mathrm{Cr}$ & $\mathrm{Pb}$ \\
\hline Agronomy farm PAU & $0.008^{\mathrm{d}}$ & $0.005^{\mathrm{b}}$ & $0.078^{\mathrm{b}}$ & $0.104^{\mathrm{c}}$ \\
\hline Jalandhar bypass, Ludhiana & $0.033^{\mathrm{a}}$ & $0.018^{\mathrm{a}}$ & $0.213^{\mathrm{a}}$ & $0.730^{\mathrm{a}}$ \\
\hline Mullanpur & $0.010^{\mathrm{b}}$ & $0.006^{\mathrm{b}}$ & $0.072^{\mathrm{b}}$ & $0.135^{\mathrm{c}}$ \\
\hline Jalandhar $\mathrm{FCl}$ & $0.004^{\mathrm{c}}$ & $0.003^{\mathrm{b}}$ & $0.045^{\mathrm{c}}$ & $0.121^{\mathrm{c}}$ \\
\hline Hoshiarpur $\mathrm{FCl}$ & $0.014^{\mathrm{b}}$ & $0.017^{\mathrm{a}}$ & $0.296^{\mathrm{a}}$ & $0.394^{\mathrm{b}}$ \\
\hline
\end{tabular}

There is no significant difference at $5 \%$ probability level between means of each column which have one common letter at least

Table 3: Mean Heavy metals concentrations in unwashed feathers from five collection sites

\begin{tabular}{|lllll|}
\hline Locations & As & $\mathrm{Cd}$ & $\mathrm{Cr}$ & $\mathrm{Pb}$ \\
\hline Agronomy farm PAU & $0.009^{\mathrm{c}}$ & $0.010^{\mathrm{c}}$ & $0.080^{\mathrm{b}}$ & $0.200^{\mathrm{c}}$ \\
\hline Jalandhar bypass, Ludhiana & $0.050^{\mathrm{a}}$ & $0.300^{\mathrm{a}}$ & $0.400^{\mathrm{a}}$ & $1.200^{\mathrm{a}}$ \\
\hline Mullanpur & $0.030^{\mathrm{ab}}$ & $0.010^{\mathrm{c}}$ & $0.090^{\mathrm{b}}$ & $0.250^{\mathrm{c}}$ \\
\hline Jalandhar FCl & $0.005^{\mathrm{c}}$ & $0.004^{\mathrm{d}}$ & $0.070^{\mathrm{b}}$ & $0.200^{\mathrm{c}}$ \\
\hline Hoshiarpur FCl & $0.020^{\mathrm{b}}$ & $0.200^{\mathrm{b}}$ & $0.400^{\mathrm{a}}$ & $0.700^{\mathrm{b}}$ \\
\hline
\end{tabular}

There is no significant difference at $5 \%$ probability level between means of each column which have one common letter at least

Table 4: Mean metal concentrations in washed and unwashed feathers from the five collection sites

\begin{tabular}{|c|c|c|c|c|c|c|c|c|c|c|}
\hline \multirow[t]{3}{*}{ Metal } & \multicolumn{10}{|c|}{ Average concentrations (ppm)- washed feathers } \\
\hline & \multicolumn{2}{|c|}{ Agronomy farm, PAU } & \multicolumn{2}{|c|}{ Jalandhar bypass, Ludhiana } & \multicolumn{2}{|c|}{ Mullanpur } & \multicolumn{2}{|c|}{ Jalandhar FCl } & \multicolumn{2}{|c|}{ Hoshiarpur FCl } \\
\hline & Washed & Unwashed & Washed & Unwashed & Washed & Unwashed & Washed & Unwashed & Washed & Unwashed \\
\hline As & $0.008 \mathrm{~d}$ & $0.009 c$ & $0.033 a$ & $0.05 a$ & $0.01 b$ & $0.03 a b$ & $0.004 \mathrm{c}$ & $0.005 c$ & $0.014 b$ & $0.02 b$ \\
\hline Cd & $0.005 b$ & $0.01 c$ & $0.018 a$ & $0.3 a$ & $0.006 b$ & $0.01 \mathrm{c}$ & $0.003 b$ & $0.004 d$ & $0.017 a$ & $0.2 b$ \\
\hline $\mathrm{Cr}$ & $0.078 \mathrm{~b}$ & $0.080 \mathrm{~b}$ & $0.213 a$ & $0.4 a$ & $0.072 b$ & $0.09 b$ & $0.045 c$ & $0.07 b$ & $0.296 a$ & $0.4 a$ \\
\hline $\mathrm{Pb}$ & $0.104 c$ & $0.20 c$ & $0.73 a$ & $1.2 \mathrm{a}$ & $0.135 c$ & $0.25 c$ & $0.121 c$ & $0.2 \mathrm{c}$ & $0.394 b$ & $0.7 \mathrm{~b}$ \\
\hline
\end{tabular}

Lines with averages followed by the same letter for the same collection site are not significantly different from each other

\section{Figures}
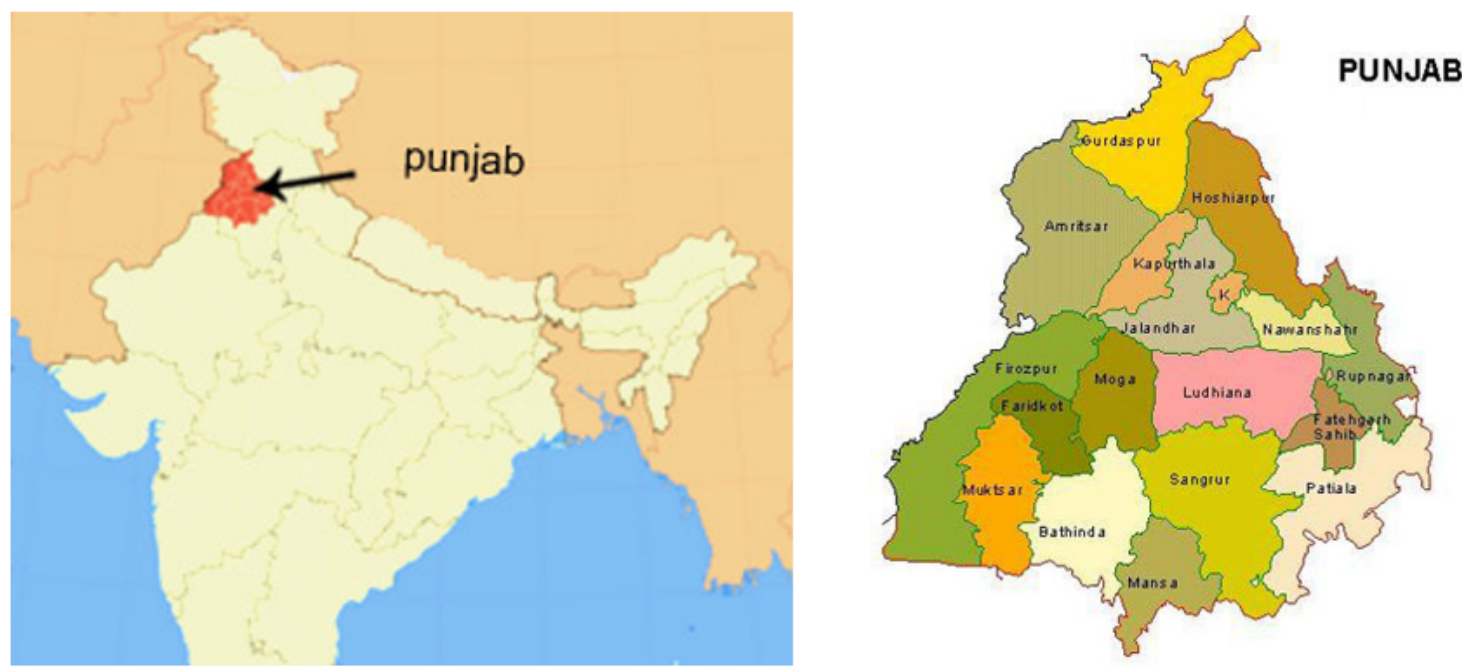

Figure 1 
Location of the state of Punjab (left) and study areas (right) which are Jalandhar, Hoshiarpur and Ludhiana Note: The designations employed and the presentation of the material on this map do not imply the expression of any opinion whatsoever on the part of Research Square concerning the legal status of any country, territory, city or area or of its authorities, or concerning the delimitation of its frontiers or boundaries. This map has been provided by the authors.
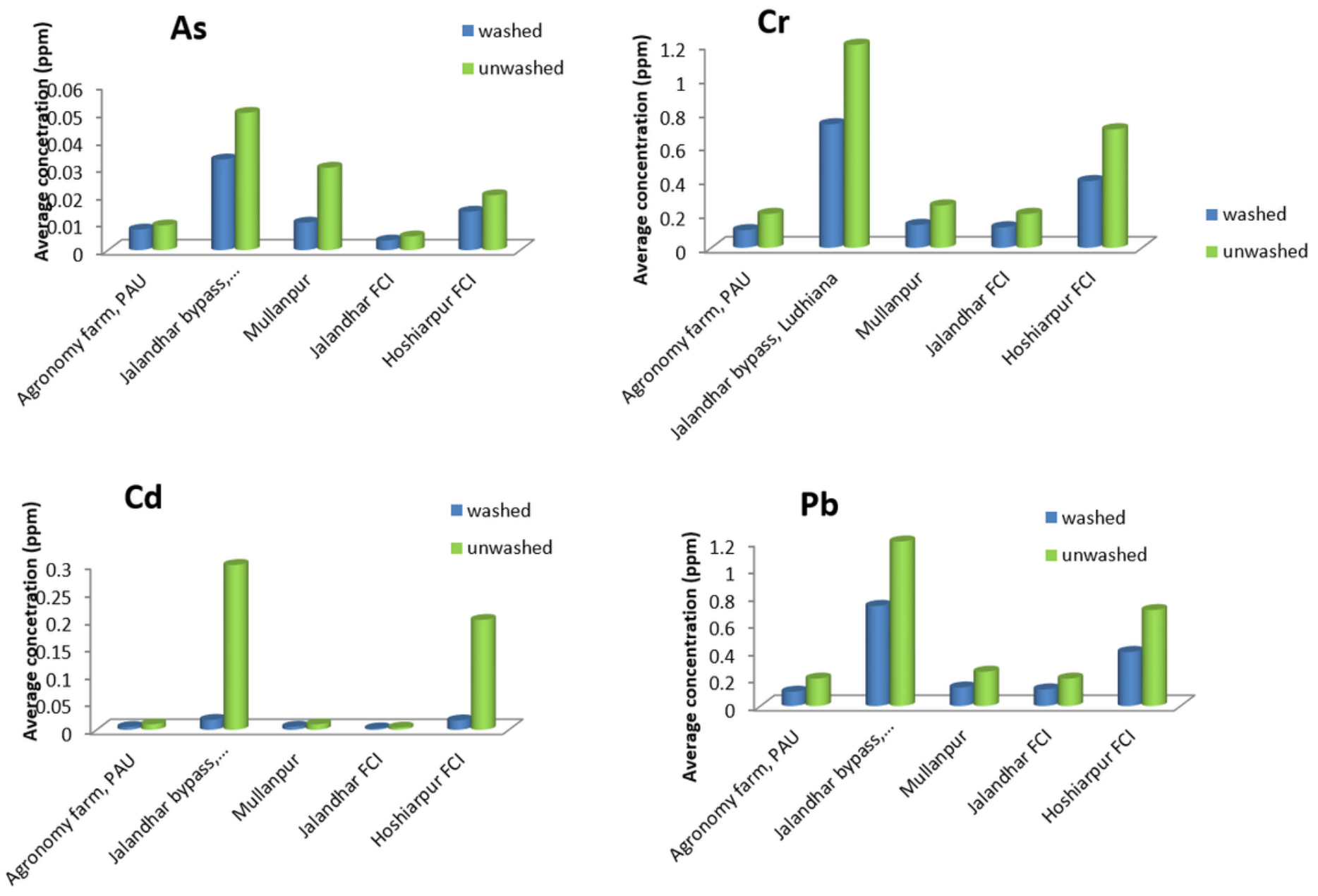

Figure 2

Mean concentrations of $\mathrm{Fe}, \mathrm{Pb}, \mathrm{Cd}$, and $\mathrm{Cr}$ in washed and unwashed feathers 